\title{
Developing Young Learners' Multiliteracies through Multimodal Storytelling
}

\author{
Lynn Mastellotto \\ Faculty of Education, Free University of Bolzano, Italy \\ lynn.mastellotto@unibz.it
}

Satisfying a rich communicative function in both linguistic and cultural terms, children's literature and storytelling present an effective approach to the development of multiple literacies in primary education. As a rich source of highquality language input, children's stories lend themselves to language and literacy work, not only in L1 but L2 as well. Learners gain language exposure in an authentic and meaningful context that stimulates their listening and reading fluency while helping them learn the rhythm, intonation, prosody and pronunciation of the target language. Picture books offer a dual-decoding experience since the text carries meaning that is enhanced by images and peritextual features, which offer visual scaffolding to help young learners unlock narrative meaning in the target language. This chapter will explore children's stories as a powerful pedagogical tool for developing young learners' functional literacy and emotional literacy. Two popular storybooks, namely Julia Donaldson's The Gruffalo (1999a; 1999b; 1999c) and Trudy Ludwig's The Invisible Boy (2013), will be examined to demonstrate how multimodal storytelling practices offer rich opportunities for communication and meaning-making activities with young learners through multisensory input that activates their learning on multiple levels.

Keywords: storytelling in primary education, multimodal picture books, English language Teaching (ELT) in primary school, literacy and young learners, multiliteracies through children's stories

\section{Introduction}

Drawing on Bruner's $(1991 ; 1997)$ understanding of the key role narrative plays in the construction of meaning, it is widely acknowledged that stories function as a powerful tool to pass on knowledge and values in a social context. Recent studies in psychology and cognitive science show that the human brain is predisposed to understand, remember and tell stories: humans think in, remember facts according to, and shape their personal and group identities along narrative structures. ${ }^{1}$ Philosophers such as Alasdair McIntyre (1981,

\footnotetext{
${ }^{1}$ See, for example, Bruner (1991), Graesser and Ottati (1995), Glaser, Garsoffky, and Schwan (2009), Rubin (1995), and Schank and Abelson (1995).
} 
216) suggest that storytelling is so central to human nature that homo sapiens, the thinking person, could more aptly be called 'homo narrans,' the storytelling person, given our propensity to organize and interpret the world in terms of narrative plots that shape our lives. Stories and storytelling thus occupy a privileged status in human cognition, offering a powerful pedagogical tool when harnessed in early learning. Learning theorists and educators point to the benefits of using stories as a strategy for designing meaningful and anchored learning experiences for young learners. ${ }^{2}$

Children's picture books and classroom storytelling practices combine different media and modes of communication to immerse children in story worlds. ${ }^{3}$ By reading stories and hearing stories read aloud, seeing stories performed through animated readings, dramatizations, roleplays and film adaptations, and by interacting with stories through tactile engagement with picture books and related cultural artefacts such as masks, puppets and lapbooks, children participate in transmedia storytelling. ${ }^{4}$ Multimodal storytelling offers rich opportunities for communication and meaning-making activities with young learners through multisensory input that activates their learning on multiple levels, as we shall see below.

The article begins with an examination of how stories, in general, are an effective teaching-learning tool that make use of different modes of communication (multimodality) to develop children's multiple literacies, from functional literacy, to visual literacy, to cognition and metacognition, as well as their social, emotional and intercultural competences. Then, through an analysis of Julia Donaldson's The Gruffalo (1999a; 1999b; 1999c) and Trudy Ludwig's The Invisible Boy (2013), the article unpacks specific modes of engagement, demonstrating how stories immerse young learners in compelling story worlds that are instructional on many levels.

\section{Multimodal Stories for Multiple Literacies}

Gail Ellis suggests that using picture books helps children develop key transversal learning competences since they ignite curiosity and nurture 'an in-

${ }^{2}$ See, for example, Järvelä and Renninger (2014), Glaser, Garsoffky, and Schwan (2009), and Mayer (2011).

${ }^{3}$ Gunther Kress defines mode as a 'socially shaped and culturally given resource for making meaning. Image, writing, layout, music, gesture, speech, moving image, soundtrack are examples of modes used in representation and communication' $(2009,54)$.

${ }^{4}$ Transmediation involves moving between and among language and art, language and music, language and film, and other ways of knowing and representing the world. Siegel defines transmediation as 'the process of translating meanings from one sign system (such as language) into another (such as pictorial representation)' $(1995,456)$. 
quisitive mindset' $(2016,30)$. Her research on 'learning literacy' (learning how to learn) demonstrates that cognitive and metacognitive skills are supported by picture books, including wordless picture books, which enable children to develop an awareness and understanding of their own learning processes (i.e. metacognition) by reflecting on their preferences, monitoring their progress, and encouraging autonomy in learning. Cognitive skills, which are more task-specific and involve children using the language and their learning materials for specific purposes - including information retrieval, sorting, classifying, hypothesizing, predicting, sequencing, and summarizing - are also supported by reading storybooks $(2016,31-2)$. Both cognitive and metacognitive learning strategies can be embedded in book-based approaches and storytelling activities in the language arts classroom and across the curriculum.

As Ellis further notes, written-linguistic modes of communication interface with oral, visual, audio, gestural, tactile and spatial patterns of meaning as teachers make use of multimodal resources for teaching and learning in the classroom; consequently, children must be able to decode information from many sources, reflect on it and discuss their learning $(2016,28)$. Janice Bland claims that through their multi-layered (i.e. readable in different ways at different levels of linguistic sophistication and cognitive maturity) and multimodal (i.e. combining written text, visual images and graphic elements) dimensions, children's stories encourage engaged analysis on many levels $(2014,2)$. This complexity helps foster children's multiliteracies, that is, not only their functional literacy (the ability to read and write) but the many different literacies- visual literacy, emotional literacy, cultural literacy and digital literacy- needed to interpret and decode information today.

The term 'multiple literacies' embraces the notion that knowledge is constructed through many sources and modes that extend beyond language itself, and children must become literate in all of these. A multi-literacies pedagogy is thus underpinned by multimodal theory which recognizes that children create meaning using a 'multiplicity of modes, means and materials' for self-expression (Kress 1997, 97). Immersive and participatory story worlds encountered through diverse media enable children to receive, reproduce and produce new stories. Kress notes that children move easily between and across modes, semiotically recycling information in creative and transformative ways according to their interests. The ability to express their thoughts, to be understood, and in so doing to act upon their culture is, according to Kress, an essential part of the child's development of a sense of agency and voice. 


\section{Functional Literacy through Stories}

As a rich source of high-quality language input, children's stories lend themselves foremost to language and literacy work with young learners. Wright $(2001,5)$ suggests that authentic stories are highly motivating and rich in language experience, allowing learners to develop a 'reservoir of language' as vocabulary and sentence constructions are introduced first through receptive learning. Reading aloud stimulates children's listening and reading fluency as they search for textual meaning and predict outcomes of stories. Listening to and telling stories help them learn the rhythm, intonation, prosody and pronunciation in $\mathrm{L}_{1}$ and $\mathrm{L}_{2}$ since stories present language through repetition and rhyme, which are predictable and memorable, thus facilitating language acquisition and retention through pattern practice. Speaking and writing fluency develop gradually as children build up knowledge of lexis and grammar, moving the acquired language into their productive control through an input-intake-output cycle wherein language exposure leads over time to language emergence (Mastellotto and Burton 2018).

Research findings on the use of storytelling with young learners of foreign languages indicate that stories contribute to the development of oral skills (Tsou, Wang, and Tzeng 2006; Wilson 1997), to a deeper understanding of syntax and story structure (Glazer and Burke 1994; Mallan 1991), and to vocabulary learning (Kirsch 2016). Young learners gain language exposure in a rich, authentic and meaningful context, first through the sounds of the language in the oral performance of a story, then gradually through the recognition of words and chunks as their literacy develops. Ghosn notes that exposure to 'rich, natural language typical of quality children's literature will facilitate the procedural memory's processing of the correct structures to the cerebellum' $(2013,134)$, and claims that, by contrast, conventional English language teaching (ELT) course books often present discourse in de-contextualised and artificial situations, thus 'minimizing opportunities for meaningful learner engagement and cognitive development' $(2013, \mathrm{xvii})$.

\section{Language Learning through Picture Books}

Julia Donaldson's international bestseller, The Gruffalo (1999a; 1999b; 1999c), is a rhyming text with natural repetition of key sounds, words, and phrases through refrains. Rhyming pairs such as wood/good, mouse/house, no/gruffalo, gruffalo/know, rocks/fox, said/sped, toes/nose, stream/ice cream, toowhoo/flew, black/back, lake/snake, hid/slid, said/bread, see/me, laughter/after, said/ahead, hello/gruffalo, see/me, rumble/crumble, said/fled facilitate sound recognition and pattern practice in the target language. Alliteration 
in the text, such as 'walk'/'wood,' 'little'/l'lunch,' also helps introduce children to the repeated initial sounds of English words and build up knowledge of phonetics. These features, which are predictable and memorable, encourage young learners' oral understanding of the English language before they begin to formally recognize graphemes and decode written text.

Given the salience of prosody and phonetics in the process of children's language acquisition, it is not surprising that translations of The Gruffalo (1999b; 1999c) have kept the main story but altered some words in order to maintain the rhyme and rhythm in the translated texts. The original lines describing the gruffalo in Donaldson's text, 'He has terrible tusks, terrible claws, and terrible teeth in his terrible jaws', instead use a variety of adjectives and introduce new cognates in the Italian translation by Laura Pelaschiar 'Ha zanne tremende, artigli affilati, e denti da mostro di bava bagnati' - in order to preserve rhyme and alliteration. Similarly, 'Where are you meeting him?'/'Here by this stream ... and his favourite food is owl ice cream' become in Italian 'E dove lo incontri?/Qui in riva al fiume... Ah ... e mangia civette con tutte le piume!' thus changing words (ice cream) in the translated text to preserve the rhyme (fiume/piume).

The verbal coup de grâce uttered by the mouse to outwit and ultimately defeat the gruffalo - 'But now my tummy is starting to rumble, and my favourite food is ... gruffalo crumble!' - is translated in Italian as 'Ma ora mi sa che ho una gran fame... che voglia di Gruffalò col salame!' which preserves the rhyme (fame/salame) while introducing a new word, 'salame,' that is culturally more appropriate to the target audience than the word 'crumble.' This is also true in the German translation by Monika Osberghaus, in which crumble is replaced by grütze (grains): 'Und jetz hab ich Hunger, mir knurrt schon der Magen. Grüfeelogrütze könnt ich heut gut vertragen!' By presenting language through repetition and rhyme, children's stories facilitate language acquisition, learning and retention through pattern practice. Listening to and telling stories helps young readers learn the rhythm, intonation, prosody and pronunciation of the target language as they begin to develop literacy.

Beyond rhyme and repetition in picture books, early literacy development is also facilitated by images and peritextual features which provide context to help young readers unlock the meaning of the text. Donaldson's text, beautifully illustrated by Axel Scheffler, contains 19 illustrations in total (two doublepage spreads), of which 9 illustrations depict body parts of the gruffalo tusks, claws, jaws, knees, toes, nose, eyes, tongue, back - helping with vocabulary learning. Another 9 illustrations present specific locations or settings deep dark wood, underground house, treetop house, log-pile house, rocks, 
stream, lake - where the story unfolds, also supporting new lexis. The contextualization provided through the book's images helps orient young readers in the story world and facilitates language work by introducing new words in meaningful situations.

The illustrations are a vital component of Donaldson's tale, rendering the storyscape more realistic and believable and, consequently, more likely to rouse readers' identification and empathy. As noted by Krashen and Bland (2014, 8), empathizing with characters in compelling stories is important for initiating young readers to the pleasure of literature. Scheffler's illustrations in The Gruffalo also help contextualize suspense and reversal of expectations as the plot unfolds, making the textual input more comprehensible by rendering the shifting feelings of the protagonist - fear, confidence strength, self-reliance - accessible to a young audience.

As the little mouse makes his way along a path through a dark wood with towering trees, his eyes gazing upward and over his shoulder, young readers are immediately drawn into the story through identification with the vulnerability of the small protagonist who finds himself in a landscape full of bigger creatures and hidden dangers. The problem of the mouse - that bigger and stronger animals want to eat him - is immediately discernible to children through their prior knowledge. Though small in size, the mouse uses his very large brain to outwit his opponents; young readers thus learn that being clever is more powerful than being big and strong as they see themselves represented by a protagonist in an engaging and empowering story.

At times, the word-image juxtaposition corresponds in picture books, in what Barthes (1977) calls 'elaboration,' whereas at other times these elements lack correspondence, what he terms 'relay.' The latter is the case in the scene in which Owl invites Mouse for tea in his treetop house: though the invitation seems on the surface to be kind, the image of the owl with glaring orange eyes and open talons ready to snatch the little mouse betray the former's true intentions. By pointing to the image and asking children whether they think owl is a friend or a foe, and whether his invitation to tea is sincere, teachers can use the illustrations as scaffolding for disambiguation and deeper understanding.

Word-image interactions can and do change in the course of one picture book, creating different types of textual-visual interanimations across a story. A thorough intermodal analysis of The Gruffalo would require a detailed and systematic description of how each image coheres with the verbal text accompanying it, which is beyond the scope of this article. However, teachers considering using this picture book with young learners should pay attention 
to symmetries and asymmetries in the intermodal messages conveyed in order to guide children's interpretation. As Moya Guijarro $(2014,68)$ explains, concurrence between image and text requires less inference since the intermodal input is symmetrical, which in turn lightens the cognitive load of the reader. In other instances, when the verbiage and image do not fully concur, scaffolding is necessary to help support young readers' understanding of the story.

Interactive storytelling activities in the classroom can provide authentic language exposure in meaningful contexts, facilitating young learners' L2 acquisition. Pre-story activities, including verbal and non-verbal warm-ups that focus on key lexis, on setting and theme, help set the stage for storytelling. This could be followed by a dialogic reading of the story, either in part or whole - pausing for clarification, sign-posting key actions and events, drawing attention to the images and graphic elements of the book - to help young learners follow the storyline and acquire key words. In the post-reading phase, the story can be revisited through dramatized storytelling which draws on different media (music, rhyme, chants, masks, puppets, scenery, mini-books, props) to enhance storytelling and re-telling. In the re-telling phase, children recycle the language they have learned, gradually moving it into their productive control.

Character-based picture books like The Gruffalo, often come with related paratext - flash cards, posters, graphic organizers, character-cutouts, songs with rhyming lyrics, suggested questions to stimulate discussion, and recommended activities - support materials which can help teachers guide children to an understanding of the story and language learning (Dunn 2012, 242).

Other post-storytelling activities can be used for empathy building in the classroom through perspective-taking tasks, such as having children adopt a character's perspective by writing a journal entry (for children with more advanced literacy) from one of the supporting characters' point of view, or by engaging in a roleplay based on specific characters and settings; for instance an imagined encounter between the owl and the snake. Extended interactive activities might include inviting children to imagine what they would bring with them on a long walk through a forest, using elements from the story as objects of realia in class - acorn, branch, pine cone, rock - and naming each object as an opportunity to recycle related lexis from the text. Bringing elements of the story world, or 'heterocosm' (Hutcheon 2013, xxiv), into the classroom stimulates children's physical interaction with the story, contributing to the transmedia storytelling experience. 


\section{Social, Emotional and Intercultural Learning through Stories}

Listening to stories in class is a social experience that allows children to share emotions as a group and forge a deep connection with others. Roney (1996, 7) notes that the 'co-creative and interactive' dimension of sharing stories makes storytelling a powerful tool for social learning in childhood. Moreover, discussing stories allows children to express a range of emotions and understand their sources. Stories link fantasy or imaginative worlds with children's real worlds, helping them make sense of their everyday lives. Stories also help children situate themselves in the world and identify ever-widening circles of belonging - home, school, community.

By transmitting cultural information (values, customs), stories help children understand their own reality and that of others, as well as construct an identity. Bruno Bettelheim (1989) and other scholars who research identity formation point to the value of stories not only in reflecting identities, but also in helping shape them. ${ }^{5}$ Since stories transmit cultural information, they are ways for children to understand what makes them the same as or different from others encountered in story worlds.

Narratives and storytelling are, in fact, part of a 'hidden curriculum' in primary education since they nurture children's psychosocial and emotional development through the transmission of values related to self-definition, empathy for and connection with others, intercultural awareness, and respect for diversity. ${ }^{6}$ Martha Nussbaum signals the ethical force of stories which help to cultivate a 'narrative imagination': through imaginary encounters with difference, readers can develop an ethical orientation by thinking about 'what it might be like to be in the shoes of a person different from oneself, to be an intelligent reader of that person's story, and to understand the emotions and wishes and desires that someone so placed might have' (2010, 95-6).

The imaginary encounters which take place through the telling and receiving of stories facilitate an engagement with other perspectives from the horizon of one's own position and experience, making self-awareness and critical distance an integral part of self-other narrative encounters. Edward Said reminds us that identities are dialogically constructed through difference: one defines oneself based on the recognition of what one is not in relation to

\footnotetext{
${ }^{5}$ See also Bennett (2001), Giddens (1991), Nehamas (1998), Nussbaum (1990), Taylor (1989).

${ }^{6} \mathrm{~A}$ hidden curriculum refers to the unspoken or implicit values, behaviours, procedures, and norms that exist in an educational setting. While such expectations are not explicitly written, 'hidden curriculum' is the unstated promotion and enforcement of certain behavioural patterns, professional standards, and social beliefs while navigating a learning environment. See Miller and Seller (1990).
} 
others; thus 'the Other' acts as 'a source and resource for a better, more critical understanding of the Self' (2004, xi). Perspective-taking tasks through reading and imaginary encounters with others can help develop empathy by enabling readers to project themselves into a character, to see the world through different eyes, and vicariously experience a spectrum of emotions. Goleman claims that 'fundamental ethical stances in life stem from underlying emotional capacities' which constitute what he calls 'emotional intelligence' $(1995$, xii).

Recent studies in psychology and behavioural science point to the value of indirect contact with diverse outgroups (immigrants, homosexuals, refugees) in educational settings as a strategy to reduce prejudice and lead to improved intergroup attitudes. Vezzali, Stathi, and Dino's (2012) and Vezzali et al.'s (2015) research with adolescents shows that indirect contact through book reading on intercultural topics can help foster an open mindset and more flexibility in perspective-taking: those who read a book with an intercultural theme showed a reduction in stereotyping, improved intergroup attitudes and intentions, and a willingness to engage in future contact with immigrants $(2012,148)$. Furthermore, the effects of indirect contact were mediated by an increased inclusion of the other in conceptualizations of the self (2012, 158).

In this way, storybooks and storytelling practices can help teachers and pupils navigate the multilingual and multicultural dynamics of today's classrooms that are increasingly defined by diversity, offering strategies to ensure that each person has a voice, is recognized, and feels a sense of belonging. A guided analysis of how identity and inclusion are represented in storybooks can provide a gateway for teachers to discuss diversity in all its dimensions, as well as issues of empathy and belonging.

\section{Stories for Social Inclusion and Empathy}

The Invisible Boy (2013), written by Trudy Ludwig and illustrated by Patrice Barton, offers rich opportunities for young learners to learn about difference through the protagonist, Brian, a young boy who feels invisible. He is ignored by his classmates and even overlooked by his teacher, Mrs. Carlotti, who is too busy dealing with certain 'problem' children in class to notice him: they 'take up a lot of space' whereas 'Brian doesn't.' (2013, unnumbered) He does not get chosen to play in games at recess because he is not among the best players,

\footnotetext{
${ }^{7}$ For a further analysis of literature and the development of emotional intelligence, see Bettleheim (1989), Ghosn (2013), Goleman (1995), Mayer, Caruso, and Salovey (1999).
} 
or the best friends of the best players, or even the friends of the best friends of the best players. He does not get invited to friends' houses or friends' birthday parties because he has no friends.

This marginal status is poignantly portrayed through Barton's illustrations: whereas the other children appear in full colour, Brian is drawn in faded shades of white and grey, always placed on the margins of the group, suggesting his isolation. By drawing attention to the images, teachers can encourage children to engage in inferential thinking - What is going on here? What do you think will happen next? How do you think Brian feels? Have you ever felt this way? - a multimodal focus which helps children develop not only textual and visual literacy, but emotional literacy as well (Bland and Lütge 2014, 7). Teachers can exploit the story's multimodality by engaging pupils first in listening to a dialogic reading that pauses to examine and comment on images, thus inviting children to interact with the text and its images.

When a new student named Justin arrives, Barton's illustrations show a similar sensitivity as the new boy stands before the class uncomfortably being sized up by his classmates. Later, some of the kids poke fun at Justin's lunch, which consists of bulgogi or barbecued beef made by his Korean grandmother. Brian observes this from his separate table in the cafeteria, 'wondering which is worse - being laughed at or feeling invisible.' (2013) As he loves to draw and is good at it, Brian leaves Justin a drawing with a note in his cubby: 'I thought the bulgogi looked good.' (2013) His empathy pushes him to overcome his own shyness and reach out to the new boy in an act of kindness.

Justin thanks him for the note at morning recess and compliments him on his drawing. Later, when it is time to pick partners in class, Emilio invites Justin and tells Brian to 'find someone else', which makes Brian wish he could 'draw a hole right there [in the floor] to swallow him up.' (2013) But Justin intervenes, suggesting they add Brian to form a trio for the group project, and Emilio concedes. Given his special talent, Brian is asked to do the drawing for the group, a recognition that makes him smile. Then at lunchtime - 'Brian's least favourite part of the day. Another twenty l-o-n-g minutes of kids talking and laughing with everyone else ... but him' (2013) - Justin waves Brian over and Emilio nods and makes room for him at their table. Sharing cookies with Justin, Brian feels like he might not be invisible after all; in fact, as he begins to be drawn into a social circle, the first blush of colour tints his cheeks in Barton's illustrations. By the end of the story, Brian appears in the same fullcolour hues as his classmates, and no longer on the fringes but at the centre of action. 
Images are a vital component of all picture books, providing details about characters' identities and their worlds, details that render them more realistic and believable and, consequently, more likely to rouse readers' identification and empathy. In The Invisible Boy, the images not only reinforce the story's message by offering visual scaffolding to support textual meaning, but also resonate on a deeply affective level as children see Brian's transformation from invisibility to visibility through the power of friendship. Bland notes that authentic picture books are powerful in early learning since the pictures transform into dynamic mental images that remain in the young reader's repertoire of experience, anchoring ideas, concepts and feelings along with new language; she states, 'the sensory anchoring supplied through the pictures in children's literature constitutes one of the most supportive features for comprehension of the text: the illustrations simplify the understanding of the verbal text both for $L_{1}$ and $L 2$ readers.' $(2015,25)$.

Ellis and Brewster $(2014,14)$ also note that using authentic storybooks can be motivating for second-language learners and can provide a greater sense of achievement then conventional ELT materials. However, the rich language of the story could present obstacles for second-language speakers since expressions like 'scurry, ' pair off,' 'is left waiting,' 'glances,' 'haven't quite made up their minds yet' are beyond the minimal language of $L 2$ learners in the 6-10 age range. Barton's images provide effective disambiguation when children's attention is drawn to the characters and situations depicted, as well as to the emotional cues suggested through the intersemiosis of text and image. Mastellotto and Burton (2018) suggest that language difficulties associated with using authentic storybooks that provide input beyond the minimal language of young learners can be overcome by fully exploiting illustrations as visual support and by using dialogic readings with scaffolded gestures and prosody to aid comprehension.

The endpapers in Ludwig's book are also beautifully illustrated and offer a further opportunity for children to negotiate textual meaning and understanding. While the front endpapers present Brian in faded grey-white tones, alone and surrounded by empty space as he draws a chalk circle on the ground, the back endpapers are colour-saturated, with Brian himself appearing in bright orange and blue as he busily draws with a chalk. Here he is surrounded by smiling and carefree classmates, all of them set in motion thanks to his chalk drawings: one is riding a rocket he has drawn, another a magic carpet, another is flying with a magic cape he has sketched, another with a set of wings. Brian's artistic talent gives them flight. Clearly, the peritextual features in Ludwig's book are a rich resource for literary and aesthetic 
interpretation; the dissimilarity in the front and back endpapers invite critical attention and problem-solving as children posit why and identify what has changed in the course of the story. They can be guided by their teacher to recognise how the endpapers help amplify the story's theme of the transformative power of friendship and inclusion.

\section{Conclusion}

Storytelling offers a dynamic, multi-sensory way to familiarize young learners with the rich tradition of children's literature in different languages by taking into account various narrative genres (fairy tales, folktales, myths, legends, fables) as well as informal narratives, and by examining how stories circulate in every culture as a means of entertainment, cultural preservation and moral education.

Through compelling picture books like Donaldson's The Gruffalo (1999a; 1999b; 1999c) and Ludwig's The Invisible Boy (2013) children gain exposure to the target language in language-rich contexts, draw connections between different translated versions of the stories or other stories with similar themes, reflect on metalinguistic connections, and enjoy opportunities to creatively retell stories and recycle language.

Furthermore, by analyzing the structural elements of stories (characters, plot, setting, narrative point of view), children learn how narrative technique is used in making meaning. Narrative literacy, the ability to 'read between the lines' of a story and understand its subtext and context, is a vital complement to functional literacy, the ability to read and write. It relies on an understanding of the pragmatic function of language, which generally evolves from ages 6 to 10 years. Narrative literacy is stimulated through new forms of media that are enhancing our ability to record, express, consume and share stories; this makes an understanding of multimodal narrative a key component of the primary curriculum. By stimulating learners' emotions and inspiring their creativity while activating their prior knowledge about how language works (metalinguistic awareness) as well as their prior knowledge about the world (metaphysical awareness), picture books are a powerful pedagogical tool in primary education. They also act as vehicles for developing young learners' emotional literacy by discussing identity and fostering inclusion in the primary classroom.

\section{References}

Barthes, Roland. 1977. Introduction to the Structural Analysis of Narratives: ImageMusic-Text. London: Fontana. 
Bennett, Jane. 2001. The Enchantment of Modern Life. Princeton, NJ: Princeton University Press.

Bettelheim, Bruno. 1989. The Uses of Enchantment: The Meaning and Importance of Fairytales. New York: Vintage Books.

Bland, Janice. 2014. 'Introduction.' In Children's Literature in Second Language Education, edited by Janice Bland and Christiane Lütge, 1-11. London: Bloomsbury Academic.

Bruner, Jerome. 1991. 'The Narrative Construction of Reality.' Critical Inquiry 18 (1): 1-21.

- 1997. The Culture of Education. Boston, MA: Harvard University Press.

Donaldson, Julia. 1999a. The Gruffalo. Illustrated by Axel Scheffler. London: Puffin Books.

—. 1999b. I/ Gruffalò. Translated by Laura Pelaschiar. Trieste: Emme Edizioni.

_.1999c. DerGrüffelo. Translated by Monika Osberghaus. Weinheim Basel: Beltz \& Gelberg.

Dunn, Opal. 2012. Introducing English to Young Children: Spoken Language. London: Collins.

Ellis, Gail. 2016. 'Promoting "Learning Literacy" through Picturebooks: Learning How to Learn.' Children's Literature in English Language Education 4 (2): 2740.

Ellis, Gail, and Jean Brewster. 2014. Tell It Again! The Storytelling Handbook for Primary English Language Teachers. London: British Council.

Ghosn, Irma K. 2013. Storybridge to Second Language Literacy: The Theory, Research, and Practice of Teaching English with Children's Literature. Charlotte, NC: IAP.

Giddens, Anthony. 1991. Modernity and Self-Identity: Self and Society in the Late Modern Age. Cambridge: Polity Press.

Glaser, Manuela, Bärbel Garsoffky, and Stephan Schwan. 2009. 'NarrativeBased Learning: Possible Benefits and Problems.' Communications: European Journal of Communication Research 34 (4): 429-47.

Glazer, Susan Mandel, and Ellen M. Burke. 1994. An Integrated Approach to Early Literacy. Boston, MA: Allyn and Bacon.

Goleman, Daniel. 1995. Emotional Intelligence. New York: Bantam Books.

Graesser, Arthur C., and Victor Ottati. 1995. 'Why Stories? Some Evidence, Questions, and Challenges.' In Knowledge and Memory: The Real Story, edited by Robert S. Wyer, 121-32. Hillsdale, NJ: Lawrence Erlbaum Associates.

Hutcheon, Linda. 2013. A Theory of Adaptation. 2nd ed. London: Routledge.

Järvelä, Sanna, and K. Ann Renninger. 2014. 'Designing for Learning: Interest, Motivation, and Engagement.' In The Cambridge Handbook of the Learning Sciences, 2nd ed., edited by Keith Sawyer, 668-85. New York: Cambridge University Press. 
Kirsch, Claudine. 2016. 'Using Storytelling to Teach Vocabulary in Language Lessons - Does It Work?' The Language Learning Journal 44 (1): 33-51.

Krashen, Sephen, and Janice Bland. 2014. 'Compelling Comprehensible Input, Academic Language and School Libraries.' Children's Literature in English Language Education Journal 2 (2): 1-12.

Kress, Gunther. 1997. Before Writing: Rethinking the Paths to Literacy. London: Taylor \& Francis.

- 2009. 'What is Mode?' In The Routledge Handbook of Multimodal Analysis, edited by Carey Jewitt, 54-67. Abingdon: Routledge.

Lazar, Gillian. 1993. Literature and Language Teaching: A Guide for Teachers and Trainers. Cambridge: Cambridge University Press.

Ludwig, Trudy. 2013. The Invisible Boy. Illustrated by Patrice Barton. New York: Knopf.

Mallan, Kerry M. 1991. Children as Storytellers. Newtown, CT: PETA.

Mastellotto, Lynn, and Graham Burton. 2018. 'Storytelling.' In Maestra Natura: per una pedagogia esperienziale e co-partecipata, edited by Liliana Dozza, 137-46. Bergamo: Zeroseiup.

Mayer, John D., David R. Caruso, and Peter Salovey. 1999. 'Emotional Intelligence Meets Traditional Standards for an Intelligence.' Intelligence 27 (4): 267-98.

Mayer, Richard E. 2011. Applying the Science of Learning. Boston, MA: Pearson/Allyn \& Bacon.

Mclntyre, Alasdair. 1981. After Virtue. London: Bloomsbury Academic.

Miller, John P., and Wayne Seller 1990. Curriculum: Perspectives and Practice. Toronto: Copp Clark Pitman.

Moya Guijarro, Arsenio Jesús. 2014. A Multimodal Analysis of Picture Books for Children: A Systemic Functional Approach. Sheffield: Equinox.

Nehamas, Alexander. 1998. The Art of Living: Socratic Reflections from Plato to Foucault. Berkeley, CA: University of California Press.

Nussbaum, Martha. 1990. Love's Knowledge: Essays on Philosophy and Literature. New York: Oxford University Press.

- 2010. Not for Profit: Why Democracy Needs the Humanities. Princeton, NJ: Princeton University Press.

Roney, R. Craig. 1996. 'Storytelling in the Classroom.' Storytelling World 9:7-9.

Rosenblatt, Louise M. 1991. 'Literature - S.O.S.!' Language Arts 68:444-8.

Rubin, David C. 1995. Memory in Oral Traditions: The Cognitive Psychology of Epic, Ballads, and Counting-out-Rhymes. New York: Oxford University Press.

Said, Edward W. 2004. Humanism and Democratic Criticism. New York: Columbia University Press.

Schank, Roger C., and Robert P. Abelson. 1995. 'Knowledge and Memory: The Real Story.' In Knowledge and Memory: The Real Story, edited by Robert S. Wyer, 1-86. Hillsdale, NJ: Lawrence Erlbaum Associates. 
Siegel, Marjoire Gail. 1995. 'More than Words: The Generative Power of Transmediation for Learning.' Canadian Journal of Education 20 (4): 455-75.

Taylor, Charles. 1989. Sources of the Self: The Making of the Modern Identity. Cambridge, MA: Harvard University Press.

Tsou, Wenli, Weichung Wang, and Yenjun Tzeng. 2006. 'Applying a Multimedia Storytelling Website in Foreign Language Learning.' Computers and Education 47 (1): 17-28.

Vezzali, Loris, Sofia Stathi, and Dino Giovannini. 2012. 'Indirect Contact through Book Reading: Improving Adolescents' Attitudes and Behavioural Intentions towards Immigrants.' Psychology in the Schools 49 (2): 148-62.

Vezzali, Loris, Sofia Stathi, Dino Giovannini, Dora Capozza, and Elena Trifiletti. 2015. 'The Greatest Magic of Harry Potter: Reducing Prejudice.' Journal of Applied Social Psychology 45 (2): 105-21.

Wilson, Julie Anne. 1997. 'A Program to Develop the Listening and Speaking Skills of Children in a First Grade Classroom.' Eric Document Reproduction Service ED 415 566. http://files.eric.ed.gov/fulltext/ED415566.pdf

Wright, Andrew. 2001. Storytelling with Children. Oxford: Oxford University Press. 